\title{
The economic impact of indirect taxes on consumersin Iraq
}

\author{
Dr.Wisal Abdullah Husain ${ }^{1}$ \\ Email:wesalab@mracpc.uobaghdad.edu.iq \\ Market Research and Consumer Protection Center,University of Baghdad \\ Assistant ProfessorOroba Main Ayesh ${ }^{2}$ \\ Email: ouroba92@mtu.edu.iq \\ Middle Technical University Technical Institute For Administration
}

\begin{abstract}
The importance of research by highlighting the impact of increasing indirect taxation on the consumer, the problem of research that the increase of the state's interest in increasing tax revenues after the decline of oil prices to cover the budget deficit without taking into account the impact of the imposition of indirect taxes on the Iraqi consumer, Therefore, the study aims to study the economic indicators to determine the extent of the effect that the tax burden is added to the prices of the materials or at the expense of their quality. And the extent to which the revenues of each type of indirect taxes, customs taxes, production and sales for 2011-2017.A number of proposals have been reached to address the imbalance associated with the imposition of indirect taxes on the Iraqi consumer.
\end{abstract}

Keywords: customs tax, production tax, sales tax, consumer

\section{Introduction}

Indirect taxes are one of the important taxes as a source of financing, but their increase leads to the transfer of their burden by the taxpayer to another cost where they are collected from the producer or the exporter or the importer in some way and the burden is on the last consumer indirectly through the high prices of goods produced or imported or bad Its quality is represented by both(Customs tax, production tax, sales tax). Through this study, the impact of the increase of these taxes on the Iraqi consumer,By studying data for the period 2011-2017. Where the research dealt with the theoretical framework, which includes a number of paragraphs namely the concept of taxation, indirect taxes concept, advantages and disadvantages,And indirect tax structure. The practical side was allocated to the economic indicators, namely the effect of the tax pressure on the general level of prices, the index of economic exposure, the index of cross-border trade, the volume of indirect taxes in Iraq, the statistical analysis of the test on the spss program to determine the effect of indirect taxes To the Iraqi consumer and finally a set of proposals was reached.

\section{1) Theoretical Framework of Research}

\section{A: The concept of tax and indirect taxes:}

The concept of taxation evolved with the development of the concept of the state. The role of taxation evolved according to prevailing economic doctrines and dominant financial thought (Naimi, 2005: 7). As a result of the development of the 
concept of taxation, the definitions have been defined. The tax is defined as "a financial obligation paid by the individual" to the state without any special benefit in return for the payment of the tax "(Mabrouka, 2006: 13). The tax can be defined as "a financial cutback that obliges people to perform government duties free of charge for public benefit" (Games, 2006: 78). The tax was also defined as "compulsory monetary deduction in favor of the public authorities in a final and without direct payment, in order to finance the public burdens of the state" (Qadi, 2011: 148).. The most common definition of tax" is that it is an arbitrary monetary deduction imposed by the financial authority or one of its formations to cover the general burdens without a specified fee" (Muhammad, 2016: 64). Its consumption, import or export is indirectly intended to charge the tax when it is spent, and to subject the capital to the tax when it is traded (Ahmad, 2007: 39).Indirect taxes also defined "the tax paid by the taxpayer and can transfer the burden of this tax to another person" (Nur et al., 2008: 18).

\section{B: Advantages and disadvantages of indirect taxes}

Indirect taxes have many advantages, notably (Khazali, 2015: 60):

A. Easy to pay for being added to the price of the item or service.

B. Economically low cost of collection.

Despite these features, they contain some flaws (Osman and Al-Ashmawi, 2007: 86):

A. Are directly affected by economic fluctuations.

B. Is imposed on income when spending or consumption, not when it is owned, and therefore the person who bears the burden of the final consumer .

C. Does not take into account the financial capabilities of taxpayers.

\section{C: Indirect Tax Structure:}

The structure of indirect taxes (Al-Kaabi, 2008: 283) (Osman and Al-Ashmawi, former source: 19) as follows:

$\checkmark$ Customs taxes are one of the most important indirect taxes and constitute a large proportion of the total tax resources in many countries of the world imposed on goods at import or export. The imposition of this tax is subject to the import and export policy followed by the state (Al-Ali, 2011: 141) Value tax "or a certain amount on each unit of the weight of a commodity, its scale, number or size, and then called a specific tax (Osman, 2008: 125).

$\checkmark$ Production taxes: This type of indirect taxes is imposed on consumer goods at the stage of their production domestically, and is calculated either by imposing a certain amount added to the price of each productive unit and obtained directly from the consumer or producer (al-Moussawi, 2017: 36).

This type of tax is determined at the final stage of production, at which the commodity becomes ready for use (Al-Ali, 2002: 142). Such taxes are very similar to customs taxes, but they differ with them in terms of pot, so that the production tax container is locally produced goods, while the customs tax container is imported goods that are produced externally (Michael, 1996: 216).

$\checkmark$ Sales tax: This type of indirect taxes is imposed on the consumption of goods and services, and is paid initially by certain categories such as the trader or the manufacturer at the time of purchase. However, these categories are quickly recovered by loading the burden on the individual purchaser or final consumer of the service or commodity (Abu Nassar et al., 2005: 483). The sales tax is defined as "the tax imposed on the goods or services during its performance and subject 
to the tax at the time of sale (Khalil and Allozi, 2013: 220)"It is an indirect tax imposed on the market of products borne by the individual when purchasing the goods or services and is based on the flexibility of supply in the markets (Hillman,2009:252). The most important advantages of the retail sales tax are more effective in the direct impact on the volume of consumption and savings As compared to other forms of sales tax due to their direct contact with consumers (Al-Shabaabah,2000:116). The disadvantages are the most difficult to apply to retail sales, especially in developing countries, because those sales are not specialized. In light of the low efficiency of the tax administration in those countries (Osman and Ashmawi, former source: 211).

\section{2: practical framework for research}

\section{A: The impact of tax pressure on the general level of prices (a}

The rate of tax pressure is what tax policy does as part of economic policy on consumer spending. The level of pressure is the rate of tax deduction to national income, which is the actual capacity of society to bear taxes as in Table( 1):-

(Table 1)The tax pressure in Iraq for the period 2011-2017 (million dinars)

\begin{tabular}{|c|c|c|c|c|c|c|}
\hline \multirow[t]{2}{*}{ year } & \multirow{2}{*}{$\begin{array}{c}\text { National } \\
\text { income(1) }\end{array}$} & \multirow{2}{*}{$\begin{array}{c}\text { Direct taxes } \\
\text { (2) }\end{array}$} & \multirow{2}{*}{$\begin{array}{l}\text { Indirect } \\
\text { taxes(3) }\end{array}$} & \multicolumn{2}{|c|}{ \%Indicators } & \multirow{2}{*}{$\begin{array}{c}\text { Tax } \\
\text { pressure } \\
2 / 1+3 / 1\end{array}$} \\
\hline & & & & $2 / 1$ & $3 / 1$ & \\
\hline 2011 & 192237070 & 873540 & 534645 & 0,45 & 0,28 & 0,73 \\
\hline 2012 & 227221851 & 1146943 & 486251 & 0,51 & 0,65 & 1,16 \\
\hline 2013 & 243518659 & 1360371 & 696849 & 0,52 & 0,29 & 0,81 \\
\hline 2014 & 237554034 & 1465261 & 574718 & 0,62 & 0,24 & 0,86 \\
\hline 2015 & 178908402 & 1723688 & 827039 & 0,96 & 0,46 & 1,43 \\
\hline 2016 & 183609461 & 3408420 & 797664 & 1,82 & 0,43 & 1,25 \\
\hline 2017 & 188310519 & 4093152 & 832710 & 2,17 & 0,44 & 2,61 \\
\hline
\end{tabular}

Source / The table was prepared by the researcher using information on national income / Ministry of Planning, Direct and indirect tax revenues / General Authority for

Taxation, Planning Department

Through the above table, the tax pressure during the years of study 2011-2017 increased gradually,And the highest rate in 2017 (2.61\%) for direct and indirect taxes, but low compared to the ideal rate of tax pressure set by (Colin Clark), which is $(25 \%)$, Proudhon set the rate of tax pressure (10\%) (pierre: 1997, 368).The effects of tax pressures vary depending on the nature of the tax. Direct taxes are imposed on income, which reduces the purchasing power of individuals and thus reduces their consumption. Indirect taxes Consumer goods by demand and prices are often higher if demand continues to rise.

Theoretical Framework of Research 
Taxes and concept of indirect taxes

The concept of taxation evolved with the development of the concept of the state and its intervention. The tax was imposed on individuals, property and institutions for the purpose of supporting public expenditure. The role of taxation was developed in accordance with prevailing economic doctrines and dominant financial thought, Initially, they were neutral in financing the state treasury and then developing their role to employ the state to achieve economic, social and political goals (Al-Naimi, 2005: 7). The concept of evolution of the concept of taxation has varied definitions The tax was defined as "a financial obligation paid by the individual" to the state without any special benefit for the payment of the tax (Mabrouka, 2006: 13). "The tax can be defined as a financial cutback that obligates people to perform government duties free of charge for public benefit" (Games, 2006: 78). The tax was also defined as "compulsory monetary deduction in favor of the public authorities in a final and without direct payment, in order to finance the public burdens of the state" (Qadi, 2011: 148). The most common definition of "taxation" is that it is an arbitrary monetary deduction imposed by the financial authority or one of its formations to cover the general burdens without a specific fee (Muhammad, 2016: 64). Indirect taxes are taxes on goods and services, whether produced, sold, traded or consumed Or at the time of import or export, aims indirectly at charging the tax when it is spent, and subjecting the capital to tax when trading (Ahmad, 2007: 39). Well I knew indirect taxes "The tax paid by the taxpayer can transfer the burden of this tax to another person "(Nur et al., 2008: 18).

Advantages and disadvantages of indirect taxes Indirect taxes have many advantages, notably (Khazali, 2015: 60): A. Easy to pay for adding to the price of the item or service.

B. Economically low cost of collection.

Despite these features, they contain some drawbacks (Osman and Ashmawi, 2007: 86):-

. Directly affected by economic fluctuations.A

B .It is imposed on income when spending or consumption, not when it is owned, and therefore the person who bears the burden of the final consumer

Trade openness is one of the indicators that measures the economy's dependence on the outside world (Hammad,2014: 47), It reflects the extent to which the country relies on foreign trade to meet consumption and production needs The proportion of 
imports from the state to GDP, when the result of measurement exceeds $21 \%$, is among the countries that are commercially open (Murad,2013:65). Table (2) shows the degree of vulnerability of the Iraqi economy for the period (2011-2017).

(Table 2)The degree of economic exposure in Iraq for the period 2011-2017 (million Iraqi dinars)

\begin{tabular}{|c|c|c|c|}
\hline year & $\begin{array}{c}\text { Value of imports } \\
(1)\end{array}$ & $\begin{array}{c}\text { Gross Domestic } \\
\text { Product( } 2)\end{array}$ & $\begin{array}{c}\text { Degree of economic } \\
\text { exposure(1/2\%) }\end{array}$ \\
\hline 2011 & 59179440 & 217327107,4 & 27,23 \\
\hline 2012 & 62135100 & 254225490,7 & 24,44 \\
\hline 2013 & 61054290 & 273587529,2 & 22,32 \\
\hline 2014 & 61221899 & 266420384,5 & 22,98 \\
\hline 2015 & 45905017 & 207876191,8 & 22,12 \\
\hline 2016 & 55001711 & 203869832,2 & 26,98 \\
\hline 2017 & 34482375 & 225995179,1 & 15,26 \\
\hline
\end{tabular}

Source / by the researcher using the data of the Ministry of Planning, Central Bureau of Statistics, National Accounts

Table (2) shows that the Iraqi economy suffers from trade dependence on the outside world. In each year (2011-2017), the gradual increase was observed by $21 \%$ in 2011-2017, which fell to $15.26 \%$ Except for the year 2017, where the percentage dropped to (15.26\%) due to the decrease in imports due to activation of the tariff for some consumer goods. However, it is considered a ratio indicating the country's dependence on imports to meet the needs of the domestic market.

\section{The cross-border trade index}

A World Bank Group indicator for a set of indicators to record the time and cost associated with the import of goods and goods. Table( 3) shows Iraq's position on the Arab Trade Index and the "Global" Agencies:

(Table 3)Cross Border Trade Index for Iraq and some Arab Countries for 2015-2017

\begin{tabular}{|c|l|c|c|c|}
\hline \multirow{2}{*}{ Arab ranking } & \multicolumn{1}{|c|}{ Countries } & \multicolumn{3}{l}{ World Ranking(189) } \\
\cline { 3 - 5 } & & 2015 & 2016 & 2017 \\
\hline 1 & & 49 & 50 & 50 \\
\hline 2 & Jordan & 76 & 69 & 67 \\
\hline 3 & Sultanate of Oman & 84 & 84 & 82 \\
\hline 4 & Palestine & 85 & 85 & 92 \\
\hline 5 & Bahrain & 107 & 91 & 85 \\
\hline 6 & Tunisia & 100 & 101 & 63 \\
\hline 7 & State of United Arab Emirates & 101 & 102 & 114 \\
\hline 8 & Morocco & 106 & 107 & 128 \\
\hline & Libya & & & \\
\hline
\end{tabular}




\begin{tabular}{|c|l|c|c|c|}
\hline 9 & Diameter & 122 & 119 & 119 \\
\hline 10 & Lebanon & 147 & 147 & 157 \\
\hline 11 & Kuwait & 150 & 149 & 158 \\
\hline 12 & Saudi & 151 & 150 & 168 \\
\hline 18 & Iraq & 179 & 178 & 178 \\
\hline
\end{tabular}

Source / The table was prepared using the report of business activities for 2016-2017 Iraq ranks 18th in the world, while the world was counted in the study 178,178 and 179 for the years 2015-2017, respectively, out of 189 countries, which is late, which indicates the high cost of imported goods and import procedures takes a long time compared to In some countries this opens the doors of financial corruption and also affects the price of goods where the importer adds the increase to transfer the burden to the Iraqi consumer.

\section{The volume of indirect taxes in Iraq}

In order to know the percentage of customs tax, production tax, sales tax and total indirect taxes, we find this in Table (4):

A table (4)The percentage of customs taxes, production and sales to indirect taxes 2011-

2017 (Millions of Dinars)

\begin{tabular}{|c|c|c|c|c|c|c|c|}
\hline year & $\begin{array}{l}\text { Indirect } \\
\text { (1) taxes }\end{array}$ & $\begin{array}{c}\text { Customs } \\
\operatorname{tax}(2)\end{array}$ & $\begin{array}{c}\text { Production } \\
\operatorname{tax}(3)\end{array}$ & $\begin{array}{r}\text { sales } \\
\operatorname{tax}(4)\end{array}$ & $\begin{array}{l}\text { Rate } \\
2 / 1 \%\end{array}$ & $\begin{array}{l}\text { Rate } \\
3 / 1 \%\end{array}$ & $\begin{array}{l}\text { Rate } \\
4 / 1 \%\end{array}$ \\
\hline 2011 & 19 & 9 & 450812 & 801 & 0,63 & 0,28 & 0,005 \\
\hline 2012 & 1486249 & 967287 & 517863 & 1099 & 0,65 & 0,35 & 0,007 \\
\hline 2013 & 2362143 & 1462963 & 596642 & 2538 & 0,59 & 0,25 & 0,001 \\
\hline 2014 & 2477253 & 1958639 & 514637 & 3977 & 0,79 & 0,21 & 0,002 \\
\hline 2015 & 2876086 & 2454315 & 416355 & 5419 & 0,85 & 0,14 & 0,002 \\
\hline 2016 & 2454576 & 1935416 & 5146 & 4523 & 0,79 & 0,21 & 0,002 \\
\hline 2017 & 2601569 & 2116322 & 480235 & 5012 & 0,81 & 0,18 & 0,002 \\
\hline \multicolumn{5}{|c|}{ Average duration2011-2017 } & 0,63 & 0,27 &, 003 \\
\hline
\end{tabular}

Source / The table was prepared using the data of the General Authority for Tax Administration / Planning

In the table above, we find that the highest rate of customs taxes on indirect taxes during the study period $2011-2017$ was $(0.63 \%)$, followed by production $\operatorname{tax}(0.27 \%)$ and finally "sales tax where the average $(0.003 \%)$, This is due to the weakness of the sectors of the national economy from industry and trade to meet domestic demand, so import was the treatment for that weakness, and despite the increase in imports as in Table (3), But the decrease in the volume of customs revenues due to the suspension of the Customs Tariff Law since its adoption in 2010, but the Tariff Act of some consumer goods has been activated after 2016 and the consumer is charged the full tax burden when demand for the product is inflexible, The supply was nonflexible, and for the production tax, the consumer was charged the tax by including it in the price of the product. As for the decrease in the sales tax, Iraq has applied 
the Sales Tax Law No. 36 of 1997 to the hotels and restaurants of the first and first class by $10 \%$ according to the first amendment issued by the Ministry of Finance in 2005 to the instructions on the fulfillment of the sales tax on the value of all the services provided by hotels And excellent and first class restaurants.Sales tax amounts are paid to the General Authority for Taxes (12) of the total (112 establishments) included in the sales tax in Baghdad and the governorates due to change of classification or evasion in addition to not adding any tourist establishment in the first class. Sales (10\%) on all goods sold except ration card items. However, the absence of an appropriate tax collection environment since the sale is in the cash payment process and not through the MasterCard (MasterCard), which will increase the evasion of the citizens and shop owners from paying the tax.

\section{Statistical analysis of research variables}

Some general statistics of variables used in researchThrough the table(5)

Some general statistics and the structure of computational experience, standard deviation, coefficient of variation of the statistical variables were obtained through the use of statistical program SPSS vr.20. Also linear regression analysis, multivariance analysis and Tche-Nha test were the first to be serviced.

\begin{tabular}{|c|l|}
\hline Code & Concept code \\
\hline b & Consumer Price Index \\
\hline c & Customs taxes \\
\hline d & Production taxes \\
\hline e & Sales taxes \\
\hline
\end{tabular}

Table (5)Some general statistics of the variables used in the search

\begin{tabular}{|c|c|c|c|c|}
\hline & & & & Coefficient of \\
& Mean & Std. Deviation & $\mathrm{N}$ & variation \\
\hline C & 1695034.7143 & 575901.16111 & 7 & 33.98 \\
d & 496740.1429 & 59711.42323 & 7 & 12.02 \\
e & 3338.4286 & 1872.38136 & 7 & 56.09 \\
b & 1436.1429 & 59.61663 & 7 & 4.15 \\
\hline
\end{tabular}

Source / The researcher prepares the table based on data from the Ministry of

Finance and the Ministry of Planning

From the table above, it emerged that the arithmetic mean of the customs taxes $(1695034,7143)$ and the standard deviation $(575901,16111)$,Arithmetic average of production taxes $(496740,1429)$ and standard deviation $(59711,42323)$, The sales tax amounted to $(3338,4286)$ and the standard deviation $(1872,38136)$. The consumer price index $(1436,1429)$ was also the average, while the standard deviation reached $(59,61663)$.As for the criterion of difference coefficient, which is the standard deviation in the form of a percentage of the arithmetic mean, we note that the coefficient of variation of the customs revenues reached $(33,98)$, and that the difference coefficient for the production taxes reached $(12,02)$, and the difference 
coefficient of sales taxes reached $(56,09)$, and the coefficient of variation of consumer price index reached $(4,15)$.It is clear that the highest coefficient of difference is the taxes and the highest coefficient of customs taxes followed by sales taxes and then the production tax, and the lowest factor was the consumer price index and this indicates that it is more homogeneous than taxes.Link parameters

\section{for search variables}

Test the correlation between the search variables, where the data in Table (5) were used to measure the level of correlation between (customs taxes, production taxes and sales taxes) with the consumer price index, Where she arrived(132,1- 140,1$142,7-145,9-148-148,1-148,4$ ) respectively for the period 2011-2017

The results were as follows:

Table (6)The correlation between the customs revenue, production, sales tax and consumer price index

Marked Correlations are significant at $\mathbf{p}<.05$

\begin{tabular}{|ll|r|r|r|}
\hline \multicolumn{2}{c|}{ Control Variables } & $\mathrm{c}$ & $\mathrm{d}$ & \multicolumn{2}{c|}{$\mathrm{e}$} \\
\hline $\mathrm{b} \quad \mathrm{c} \quad$ Correlation & 1.000 & $-.743-$ & .959 \\
& Significance (2-tailed) &. & .090 & .002 \\
& $\mathrm{df}$ & 0 & 4 & 4 \\
\hline & Correlation & $-.743-$ & 1.000 & $-.770-$ \\
& Significance (2-tailed) & .090 &. & .073 \\
& $\mathrm{df}$ & 4 & 0 & 4 \\
& Correlation & .959 & $-.770-$ & 1.000 \\
& Significance (2-tailed) & .002 & .073 &. \\
& $\mathrm{~d}$ & 4 & 4 & 0 \\
\hline
\end{tabular}

As shown in the table data, there is a very strong correlation between the index and sales taxes, as opposed to both production taxes and customs taxes where the correlation relationship was negative, ie, a change in production taxes or customs taxes would have an adverse effect on the index.

\section{Simple linear regression model}

A) By analyzing the results of the test the significance of the effect between the independent variables is $(0.88)$ which means that the adoption of the tax (customs, excitement and sales) will explain 0.88 of the variables in the index and that only $(0,12)$ The standard form is caused by other factors of the monta simple linear regression model and as follows Schedule: Table ( 7 )Simple linear regression between variables (kinetic, production, sales) and index

Model Summary

\begin{tabular}{|c|c|c|}
\hline $\mathrm{R}$ & R Square & Adjusted R Square \\
\hline $.971^{\mathrm{a}}$ & .944 & .887 \\
\hline
\end{tabular}

a. Predictors: (Constant), e, d, c B-multiple variance analysis 
The results of the summary of the analysis of variance showed that the calculated $F$ value is $(16,753)$ while the value of the table $F$ is 9,276 . This confirms the importance of the existence of the independent variables in the simple linear regression model and the acceptance of the relationship form.

Table (8)Analysis of variance in regression model

\begin{tabular}{|ll|r|r|r|r|r|}
\hline \multicolumn{1}{|l|}{ Model } & & Sum of Squares & $\mathrm{df}$ & Mean Square & \multicolumn{1}{c|}{$\mathrm{F}$} & Sig. \\
\hline 1 & Regression & 20123.627 & 3 & 6707.876 & 16.753 & $.022^{\mathrm{a}}$ \\
& Residual & 1201.230 & 3 & 400.410 & & \\
& Total & 21324.857 & 6 & & & \\
\hline
\end{tabular}

a. Predictors: (Constant), e, d, c

b. Dependent Variable: b

\section{C- T test}

It is clear from the summary of the Coeffecients table that the calculated $t$ value is $(10,020)$ below the level of significance $(0,05)$, and the calculated t was greater than the tabular $t$ value below the level Indication of $5 \%$ in one category / non-negotiable

Table (9)Analysis of variance of regression model

\begin{tabular}{|c|c|c|c|c|c|c|}
\hline \multirow{2}{*}{\multicolumn{2}{|c|}{ Model }} & \multicolumn{2}{|c|}{ Unstandardized Coefficients } & \multirow{2}{*}{$\begin{array}{c}\begin{array}{c}\text { Standardized } \\
\text { Coefficients }\end{array} \\
\text { Beta }\end{array}$} & \multirow[b]{2}{*}{$\mathrm{t}$} & \multirow[b]{2}{*}{ Sig. } \\
\hline & & $\mathrm{B}$ & Std. Error & & & \\
\hline \multirow[t]{4}{*}{1} & (Constant) & 1242.812 & 124.033 & & 10.020 & .002 \\
\hline & $\mathrm{C}$ & $-6.133 E-5$ & .000 & $-.592-$ & $-.613-$ & .583 \\
\hline & $\mathrm{d}$ & .000 & .000 & .265 & 1.737 & .181 \\
\hline & $\mathrm{e}$ & .050 & .030 & 1.561 & 1.638 & .200 \\
\hline
\end{tabular}

a. Dependent Variable: b

\section{1-for the customs tax variable}

The calculated $t$ value is -0.59 . The tabular $t$ value $(2,353)$ is that $t$ calculated less than the tabular and thus accepting the null hypothesis that there are no significant differences between the customs tax averages.

\section{2- For the variable of production taxes}

Calculated value $t(1,737)>T$ value $(2,353)$ is under freedom degree $(3)$ and significant level $(5 \%)$, meaning that a hypothesis is accepted between the sales tax averages.

\section{3-For the sales tax variable}

The value of $t$ calculated $(1,638)>$ the $t$-value of $t$-table $(2,353)$ under the degree of freedom (3) and the level of significance $5 \%$, ie, the null hypothesis is accepted, that is, there are no significant statistical differences between the averages of sales taxes. 
Proposals1. Application of the electronic system at the border crossings to control the provisions and to eliminate financial corruption.

2. Activation of the customs tariff on goods, of which there is a productivity factor in the country, because customs taxes occupy the largest proportion of indirect taxes . 3. Taking anti-dumping measures by specifying a customs tariff equivalent to the margin of dumping, if the price of exporting the imported product to Iraq is less than its true value.

4. To impose the sales tax at reasonable rates determined by economists and financial experts and impose the ratio according to the type of product or service provided.

5. Continuing the exemption of the necessary goods from the customs tax, considering that these commodities are more burdensome to the consumer with low incomes, especially commodities and agricultural products and basic.

6. Analysis and identification of the high cost of imported goods and increase the time of import procedures in Iraq compared to other Arab countries.

\section{Sources}

1. Abu Nassar, Muhammad, Al-Mashaala, Mahfouz, Al-Shahwan, FirasAtallah, Tax Accounting Between Theory and Practice, Third Edition, World Constitution Printing Press, Amman, 2005.

2.Al-Kaabi, Jabar Muhammad Ali, Tax Legislation in Iraq, Second Edition, Dar AlSajjad, 2008.

3.Al-Shawabkeh, Salem Mohammed, Public Finance and Tax Legislation, Dar Rafid, Amman, 2000.

4.Ahmed, Mohsen Ibrahim, Evaluation of the effectiveness of the tax system in Iraq for the period (1980-2005), PhD thesis, Faculty of Management and Economics, University of Sulaymaniyah, 2007.

5.Othman, Said Abdul Aziz and Ashmawi, Shukri Rajab, Tax Economics, University House, Alexandria, 2007.

6.Naimi, Rasha Abdul Majid Saeed, Tax Evasion in Medical Professions, Master Thesis, Faculty of Management and Economics, University of Baghdad, 2005.

7.Mabrouka, Hegaz, The Impact of the Tax Policy on Investment in the Institution, Faculty of Economic Sciences, University of Mohamed BouDiaf, Algeria, 2006.

8.Ali, Adel, Public Finance and Financial and Tax Law, Thira Publishing and Distribution, Jordan, 2011.

9.Ali, Adel Fleih, Public Finance and Taxation Tax Legislation, University of Mosul, 2002.

10.Al-Khazali, RihatJafat Abdullah, After the Change of Financial Policy on Tax Revenues, Research Presented to the Higher Institute of Accounting and Financial Studies, University of Baghdad, 2015. 
11.Khalil, Ali Mohamed, Al Lozi, Sulaiman Ahmed, Public Finance, Dar Al Yusra Publishing and Distribution, Amman, 2013.

12.Al-Mousawi, Nihad Abdel-Abbas Mohan, Analysis of the role of the tax system in the preparation of a federal federal budget in Iraq, a research submitted to the Institute of Higher Accounting and Financial Studies, University of Baghdad, 2017.

13.Osman, Said Abdul Aziz, The Tax System and Community Targets, Contemporary Analytical Approach, University House, 2008.

14.Qadi, Abdul Majid, Studies in Taxation, First Edition, Dar Al-Thaqafa for Publishing and Distribution, Amman, 2011.

15.Hammad, Akram Ibrahim, The degree of Arab exposure and dependence abroad, 2014.

16.Mourad, Sawley Murad, Commercial openness and its impact on monetary and monetary policies, a standard study, Journal of the Future Arab, No. 417, 2013.

17.Nour, Abdel Nasser and Adas, Nael Hassan and Cherif, Alyan, Taxes and Accountability, Second Edition, Dar Al Masirah Publishing, Distribution and Printing, Amman, 2008.

18.Mohammed, Amr Hisham, Introduction to Public Finance, First Edition, Dar AlDoctor for Administrative and Economic Sciences, Baghdad, 2016.

19.Michael . P , " The Economic of Tax policy , Oxford University press , London ,1996.

20. Hillman, Arye L, Public Finance and Public Policy, Second Edition, Published in the United States of America by Cambridge University Press, New York,2009.

21.Pierre Beltrame ,LucienMehl,Tehnique,politiques et institution fiscalescompares,PUF,France 1997.

22. Games,Andrew and Birch ,kean,Bublicsector spending and Regional Economic Development University of Glasgow ,center for Advanced studies .Uk,2006. 